Article

\title{
Canines in the Classroom: Boccaccio, Dante, and the Visual Arts
}

\author{
Julia Cozzarelli \\ jcozzarelli@ithaca.edu; Tel.: +1-607-274-3513 \\ Academic Editor: Patricia Emison \\ Received: 19 January 2016; Accepted: 15 August 2016; Published: 18 August 2016
}

Department of Modern Languages and Literatures, Ithaca College, 953 Danby Rd, Ithaca, NY 14850, USA;

\begin{abstract}
The article has two primary objectives: it presents an analysis of the representation of animals in selected Italian literary works; and it utilizes that analysis as an example of how to incorporate the visual arts in teaching literature in the undergraduate classroom. The literary works discussed include Dante's Inferno and the myth of Romulus and Remus as preparation for Boccaccio's Decameron, specifically novelle IX.7 and V.8, with a thematic focus on portrayals of canines. The article argues that the use of artwork from the medieval and Renaissance periods, such as statuary, illustrated manuscripts, images in bestiaries, and works by Botticelli and other well-known artists, can be used to complement and reinforce interpretations of the texts, and are a powerful and effective tool in the learning process.
\end{abstract}

Keywords: Boccaccio; Decameron; Dante; Botticelli; dogs and wolves; visual imagery; pedagogy

\section{Introduction}

Literary scholars consider Boccaccio's Decameron to be one of the seminal works that ushered in the Italian Renaissance, marking Florence as its very birthplace. The Decameron is situated on the threshold of humanism, and of a prolific period of transformation not only in literature, but also in the fine arts. Given the intimate relationships between written literary works and the visual arts, instructors are not limited to presenting Italian literature as an independent discipline whose interpretation is sought and expressed through text alone. In this essay, I discuss a thematic exploration of Dante and Boccaccio in an undergraduate literature course that uses artwork to enhance the student learning experience. My intent is to underscore the value of making such interdisciplinary connections, with my own teaching experiences serving as an example of one approach to the subject. Although there are challenges inherent in teaching Boccaccio's writings in the undergraduate classroom, teaching at this level can also provide opportunities for creative approaches to the subject matter, and the inclusion of multiple disciplines is supported by the growing emphasis on interdisciplinarity prevalent on so many college campuses today. My focus here is the use of animal imagery, in particular, as an interpretive aid to the novelle of the Decameron and associated portions of Dante's Divina commedia.

The contexts in which I teach the Decameron are varied, including an upper-level course dedicated to the text and taught completely in Italian; a survey of Italian literature course taught in translation and populated primarily by Italian majors and minors, in which we study a segment of the work; and a first-year core curriculum seminar taught entirely in English to students from a wide range of majors, in which we discuss a small selection of novelle. As is the case in many undergraduate programs, our Italian courses at all levels aim to integrate not only language learning, but also literature and culture, so this content can easily be adapted to a range of offerings. The Decameron is an effective tool for illustrating associations with other critical works of literature, and examining the portrayal of animals is one way to motivate students to make these connections on their own. Visual imagery and animals are, in fact, closely linked, for animals were a fundamental component of Florentine life in 
the 14th century; not only as practical resources, but also as figures populating bestiaries, fables, and legends, and their symbolic images abound in artwork from the period.

This essay, then, brings together Italian literature, the visual arts, and pedagogy. Its core is my analysis of the texts through a study of canine representations, which is an area that has not yet been explored in depth in the field of Italian Studies. I do not present this content to the class in the form of teacher-centered lectures or readings, however. Rather, these underlying ideas support and guide my teaching approach, which is a student-centered and open-ended means to reach my ultimate classroom objective: to facilitate discussion of the texts while encouraging students to think critically about their content and their own reactions to that content, not only in their historical and literary contexts, but also as works that are still relevant today. Supplementing a study of literature with the visual arts they inspire reinforces memory and learning in our students (who display a variety of learning styles) and provides an opportunity for students to be inspired themselves.

The integration of visual imagery in the curricula reflects an overall approach to teaching literature, and is not limited to the Decameron. The Decameron, however, presents a number of opportunities for this practice due to the fact that its widely-read novelle were often rich sources for artistic inspiration. Moreover, the visual arts can also be engaged in presenting the lesser-known novelle. I touch upon two examples from Boccaccio in this essay-content that typically occupies two to four lessons (depending on the course), but with a methodology that can be used for a full semester. The examples I have selected are effective as focal points for animal imagery—and, for our purposes here, canines.

\section{Context and Approach: Dante, Wolves, and the Founding of Rome}

In any course in which we read Boccaccio's works, it is important that students already have, or are given, some familiarity with Dante Alighieri's profoundly influential Divina commedia. It is primarily through the Commedia, and the exploration of the beasts that are so intimately connected with it, that the students are first exposed to the use of the visual arts in our classroom. Therefore, an exploration of Dante's masterpiece and associated animal icons is an essential aspect of my approach to teaching Boccaccio's text. The Commedia's allegorical world is inhabited by fantastic, terrifying beasts, and hybrid monsters with mythological roots; it epitomizes animal representation in medieval literature. Canines often play a prominent role, with the famished she-wolf of Inferno I taking center stage, so the Canidae family (which includes wolves and dogs) is an option well suited for use as an interpretive key to the works of both authors. The she-wolf, or lupa, serves as a representation of the sins tormenting Dante's pilgrim, but she is also a beast with a profound literary heritage in Italy, including her status as the symbol of Rome.

To open the discussion on the she-wolf with students, especially in the first-year seminar where their exposure to Dante is nearly non-existent, we first review the foundational myth of the she-wolf who rescued and suckled Romulus and Remus, the twins linked not only to Rome (established by Romulus after the murder of his brother), but also to Siena (founded by Remus' sons). Prominent images of the she-wolf suckling the twins abound in these cities, and appear in other regions as well. Students who have traveled to Italy often recollect seeing the statues without understanding what they represent, and the icon is so prolific that an instructor can find countless examples. Students read the myth as homework to prepare for the lesson, and can also be asked to find examples of the icon online.

All of our lessons, including this one, begin in a similar way-with a series of warm-up questions designed to gauge the students' preliminary response to the assignment and to encourage them to share any aspects found challenging or rewarding. This is initially done in pairs or small groups, with follow-up as a class. Like the warm-up questions that are traditionally included in courses focused primarily on language skills, these opening exercises reduce student anxiety (thereby positively impacting affect, a key to learning) while simultaneously checking general comprehension, which is particularly important with courses taught in Italian. After we review the general details of the foundational myth in class (again, through guided discussion in pairs or groups), we move on to study the images associated with it, including any that the students may have found on their own. With 
each image, the instructor can shape the classroom conversation, first by asking students open-ended questions about what they are seeing, and then by following up or expanding on their replies, and finally supplementing with any information that the students did not touch upon.

In class, I draw particular attention to a few specific pieces. From Rome, where the myth was born, the students see the famous Capitoline wolf, a bronze statue of unclear origin that was traditionally attributed to Etruscan artists of the fifth-century BC, and more recently thought to be a product of the Middle Ages. She stands above the boys, teeth bared as she looks out at the surrounding world, with the twins straining upward to reach her swollen teats. This is the classic symbol of Rome. When asked, most students report that the image conveys a clear sense of the ferocity of the animal, and her gauntness is inseparable from her great hunger. The naked infants she towers above appear small, vulnerable, and exposed.

A later representation we examine from outside of Rome is the bas-relief in the lower basin of Nicola and Giovanni Pisano's 1278 Fontana maggiore in Perugia's main square. Here, the boys appear in the foreground, and, although they are suckling from the wolf, they are facing one another with arms raised in what could be seen as a confrontational stance. This wolf seems comparatively mild; she is seated, with mouth closed, her head twisted around to look into the woods. This myth of Rome's foundation appears alongside several other images on the fountain, including those representing fables, biblical tales, and symbols of the zodiac and the liberal arts. The she-wolf is positioned next to a panel depicting the human mother of the twins; and nearby, there are two other panels representing wolves from fables in far less nurturing roles.

The date of the Fontana maggiore's construction is too early to claim any direct influence from Dante's work, although Dante would have been familiar with the abundant images of the she-wolf, if not the Perugia fountain itself. Rather, the fountain and the Commedia are examples of a parallel movement in art and literature. The artwork represents, visually, what we see in written form in Dante's writing: early signs of the enthusiastic embrace of classical works that would reach its peak in the humanism of the Renaissance. Therefore, the Fontana maggiore can be used in a number of ways in the classroom. As a work contemporary with that of Dante and close to the time of Boccaccio, instructors can utilize its structure and images to explore political, historical, artistic or thematic issues from the period, as well as the way in which symbolic images were used to convey meaning. The more immediate effect of considering such images in the literature classroom is to underscore the ubiquitous nature of the foundational myth and its featured animal figure for the populace of the time. This can help students to view the myth less as an obscure tale than as a universally-shared cultural influence. In turn, the she-wolf can then be approached not only as a literary phenomenon, but as a widespread cultural icon. Students exposed to artwork as context can also more carefully consider how Dante and Boccaccio's wolves were either similar to or different from those that came before and after, and how views towards the animals have continued to evolve over time.

After the Fontana maggiore, we turn to Siena's she-wolf, who does, in fact, feature in the city's foundational myth, which was derived from that of Rome. She is represented throughout the city, often in forms that imitate the Capitoline wolf, but also in more original poses. Overall, she is characteristically featured as a gaunt animal with protruding ribs that stands over the boys in an alert and tense posture. She is frequently, but not always, shown baring her teeth. Examples of the she-wolf in Siena include the c. 1429 bronze statue by Giovanni di Turino that once stood outside the Palazzo Pubblico; a prominent mosaic set into the floor of Siena's impressive medieval duomo; and her inclusion in Ambrogio Lorenzetti's fresco, the Allegory of Good Government from 1338-40. A comparison of Rome and Siena's she-wolves also illustrates the close ties, and simultaneously, great differences, between verbal and visual representation. Cristina Mazzoni, who has authored a monograph dedicated to the Roman icon, emphasizes that Siena's she-wolf myth is adapted from an ancient Roman legend which has a far longer, more complex, and much more ambiguous origin. Moreover, the Roman myth was transmitted primarily through verbal means, whereas the more recent Sienese version is embodied by a profusion of artistic images - visual representation derived from an 
"unreliable (because legendary) verbal representation", that "adds another layer of doubt" to the tale itself ([1], p. 204). ${ }^{1}$

To reiterate: although much of this is information an instructor may ultimately have to supply to the class, the point of entry is through questions to the students. They are asked to express the impact the images have on them, and whether the impressions from the images affect how they feel about either the images themselves or the myth they represent. When we examine these icons in class, most students report positive feelings towards the wolf as she is represented, with protectiveness and nurturing as her main features. However, her snarling stance and prominent ribs underscore her nature as a dangerous beast, reminding us that the symbol itself is not without ambiguity, and that this ambiguity is not only due to the fratricidal destiny that awaits the infants she nurses. Mazzoni notes that the myth of the she-wolf, and the image of her nursing human boys, raises questions about the "relationship between nature and culture," and, because of the closeness of the two species in this image, "visual and textual, physical and imaginative ways must be found...to reestablish difference in order to assert our humanity" ([1], p. 7). The she-wolf, already innately ambiguous as a symbol, epitomizes this process of distancing by association. Over the centuries she has been, and continues to be, closely tied to misogynistic representations of female desire, reflected in the persistent use of the term lupa for a female prostitute ([1], p. 1; [2], p. 164).

Students can be given a sense of the she-wolf's negative connotations through these myths, but it is her representation in the Commedia that fully embodies the era's widespread notion of the wolf as an icon of rapacity ([2], p. 162). The Inferno's wolf is neither maternal nor protective, and its verses describe the animal as ravenous and insatiable, qualities intimately tied to the sin she represents, introducing her as "una lupa, che di tutte brame/sembiava carca ne la sua magrezza" (a she-wolf, that in her leanness seemed laden with every craving) ([3], Inf. I vv. 49-50). ${ }^{2}$ The wolf's characterization as the most persistent of the three iconic beasts in the Inferno's opening canto ensures her inclusion in virtually any efforts to illustrate the Commedia.

Indeed, this opening canto is so powerful and influential, that it works very well for another technique I regularly employ in my courses: asking students to draw one or two key passages in class (even stick figures will do), either individually or in pairs, after having read the canto for homework. There are a number of reasons for this approach. First of all, it demonstrates how well the students comprehend and/or retain what they read (sometimes I ask them to work from memory, and at other times, while referring to the text); it is an exercise students enjoy, which, again, reduces anxiety and enhances affect, helping them to learn; and some recent studies support the idea that "doodling" in class not only makes learning more enjoyable, but also assists the brain in the learning process (see [4]).

After the students share, discuss, and then, perhaps, modify their sketches of Inferno I, we turn our attention to the experts. Using PowerPoint projections, I lead them through a series of images that span the seven centuries since the Commedia was written. This brief overview gives students a taste of how the visual arts changed over time, and how the artwork reflects not only its historical context, but also shifting interpretations of literary texts. We begin with pages from illustrated manuscripts (MS. Holkham misc. 48 [5] from late 14th century, and Yates Thompson MS 36 [6] from c. 1444-52), where with less than 100 years of movement into the Italian Renaissance, marked differences are already apparent in the artwork. To assist students in interpreting the illustrations, it is helpful to explain some common practices in them, such as the tendency for the illustrators to label the characters they depict, and the practice of representing the passage of time with multiple versions of individuals within the

1 See Cristina Mazzoni for an in-depth study of the icon of the she-wolf in art, history, and literature. Mazzoni also examines the significance of the Pisan fountain's images, including discussion on how the wolves reflect the complex relationship between Perugia and Rome ([1], p. 200).

2 Dante's Virgil echoes this language, saying "questa bestia...ha natura sì malvagia e ria,/che mai non empie la bramosa voglia,/e dopo 'l pasto ha più fame che pria" (this beast...has a nature so vicious and malign that she never sates her greedy appetite and after feeding is hungrier than before) ([3], Inf. I vv. 94-99). 
same frame. Students see how the earlier examples' compressed, strongly linear, two-dimensional representations are later replaced by figures that are more voluminous, in settings that convey a sense of depth in the composition. The beasts have shifted from static, cartoon-like representations to become aggressive attackers, with the pilgrim's fear and physical danger readily apparent. These early images, which are the closest historically to when the Commedia was written, can be used to again demonstrate that literature and the visual arts were undergoing a somewhat parallel process of change. The early works are less concerned with accuracy, and are more focused on imparting a sense of what the text, which is intended to be read at additional levels beyond the literal, contains. It is up to the reader to explore the meaning of both art and written word more deeply. In another sense, however, Dante's illustrators were also lagging behind him: his sophisticated, incredibly complex encyclopedic genius was, after all, one of the drivers of the great changes to come in literature and thought. Moreover, the early illustrations were meant to render the manuscripts more ornate for selected audiences; they were not intended to stand on their own. To give a greater sense of the works' context in the visual arts, manuscript illustrations can be supplemented by selected contemporary works, such as the Bargello's fresco portrait of Dante that is attributed to Giotto, an artist whose work more strongly portended new developments in the visual arts.

While early visual images are helpful in providing context, later works, which are much more closely identified with specific artists, can be used to show how aesthetic norms changed over time. In periods where realism was valued, the images become much more life-like, although often this realism does not extend to literal interpretations of the text, either because the artist was not familiar enough with the work, or deliberately chose to represent its contents in a different way. A few of the images I like to show for Inferno I include those of Sandro Botticelli, John Flaxman, William Blake, Gustave Doré, and Salvador Dalí. Each of these images is remarkably different and can inspire enthusiastic class discussion. They also work well on their own as representative images for instructors who prefer to limit the scope of the artwork to be discussed. Students should be encouraged to share any impressions shaped by their own disciplines, and those who have studied art history can be invited to express their thoughts as well. This helps to build rapport in the classroom and inspires students to make connections between the subject of the lesson, other branches of knowledge, and aspects of their own lives.

To conclude this exercise, students are asked to discuss which visual images struck them most and why, as well as how the three beasts of Dante's wood were represented in their picks. Such conversations will, naturally, be shaped by the interests of the students, and comparisons between illustrations can also lead to discussions of how the artwork reflects perceptions of wolves that may or may not have changed over time. Ultimately, however, the lesson is intended to impress upon students the importance of allegory in medieval works, and how Dante's beasts embodied this tradition, even as the poet took literature into dramatically new directions with his masterpiece.

The extent to which the visual arts are included in lessons such as these depends on the goals of the instructor and the aims of the lesson. The impressions students take away from the images do have the power to affect their interpretation of a text. For example, the protective stance of the wolf-as-mother from the tale of Romulus and Remus can seem at odds, to some, with the relentless she-wolf represented in Dante's trio, for images emphasizing her nurturing side can overshadow her association with darker elements, including her misogynistic connotations. Conversely, images representing the she-wolf at her most gaunt and savage can override the positive associations of her role in early literature. However, this is, in fact, a primary purpose for exploring these works in the classroom. They function in a way similar to that of contemporary critical studies of literary texts: both artwork and literary criticism are examples of the interpretation of an original text by another person (be it artist or scholar). It is up to our students-with our help as instructors-to determine which interpretations they favor and why, and to begin to develop their own interpretations of the originals. 


\section{Boccaccio's Beasts and the Bestiary}

Once the students have a sense of the canine representations in earlier Italian literature, we are ready to discuss the topic in Boccaccio's works. Boccaccio must have been aware of the wolf as a symbol of avarice and rapacity, and this knowledge was clearly evident by the time he wrote his expositions on the Commedia. In his allegorical exposition on Inferno I, Boccaccio describes the transformative nature of sin, through which sinners lose their humanity by allowing their carnal desires to subsume their reason, with the assertion that "il rapace diventa lupo, perché il lupo è rapacissimo animale" (the rapacious man becomes a wolf because the wolf is a rapacious animal) ([7], I.II.73; [8], p. 91). ${ }^{3}$ Boccaccio describes Dante's she-wolf in the dark wood as a "fiero animale e orribile" (ferocious and horrible animal), "famelico e bramoso" (ravenous and greedy), associating her with avaricious and greedy people ([7], I.II.125-33; [8], pp. 100-1). Moreover, he explains, the she-wolf is also equated with the devil, as a "rapacissimo ed insaziabile divoratore" (exceedingly rapacious and insatiable devourer) who threatens human beings with ruin ([7], I.II.141; [8], p. 103).

The wolves in the Commedia, and in Boccaccio's expositions, are representative of a time when studies of animals were intended to teach us about humanity rather than animals themselves, and animal behavior was interpreted symbolically in the moral exemplars of the influential Physiologus and the bestiaries that derived from it ([9], p. 1). ${ }^{4}$ Mythological and fantastical creatures held equal standing with the living in these works, which drew their authority from the Bible and other ancient texts, rather than from observation of the creatures themselves. In any discussion of animals in Italian medieval or Renaissance literature, images from bestiaries can be used to bring their theological and philosophical context to life for students. For quick access in class, bestiary images are available in a number of online resources, such as The Medieval Bestiary, a website that includes a gallery of images for each animal [10].

It may come as no surprise that the creatures in the Commedia, who are largely mythological and/or symbolic, share commonalities with those of the bestiaries. However, the Decameron is dramatically different in style, structure, and content from the Commedia, and its animals, much fewer in number, are typically the utilitarian beasts of daily life. Nonetheless, Boccaccio's animals are not simply manifestations of a more realistic approach to the portrayal of living things. Rather, they are a fusion of a naturalistic approach and the symbolic tradition, and traces remain of their theological and allegorical roots.

The wolf also appears in the Decameron, with its largest role in novella 7 on Day IX. This is one of the work's shorter novelle, featuring Talano d'Imole's prophetic dream in which his beautiful but argumentative wife Margherita is attacked and disfigured by a wolf in the woods. Although this is not one of the Decameron's more widely-read tales, it is an excellent choice for bringing the bestiaries to life in the classroom, and it also serves as an example to students of how even a "minor" novella can be explored in detail.

The selection of tales for our course, in fact, serves as a living example of the variety and depth of Boccaccio's masterpiece, and of how the goals in its study change over time and according to circumstance. Students of literature approach these tales from a very different perspective than that of artists in the past, whose work was their livelihood and whose choices were frequently dictated by those who supported them. While the literary scholars and professors of today do explore such works as part of their profession, their own interests are what determine which areas they choose

3 Boccaccio also explains the appellation of Pluto as a wolf in Inferno VII as logical, given the sin the circle punishes: avarice ([7], VII.I.13; [8], p. 333).

4 In the Bestiario toscano, for example, a fable relating the interaction between a wolf and a deer is used to equate the wolf with the devil, and to urge the human faithful to drive away the devil with good deeds rather than sin. The Bestiario also contains a reference to the she-wolf's habit of selecting the most miserable of mates ([10], pp. 73-74, 89, 90). The moral exemplars were also evident in early Italian literary excerpts. See, for example, the legend of St. Francis and the wolf of Gubbio, where the wolf is used to represent corruption and sin, and St. Francis' taming of it indicates the ability of religion to reform the soul. 
to investigate at length; and in the undergraduate classroom, literary interpretations are intended to teach critical thinking skills that students can expand upon and employ in other, non-literary areas throughout their lives.

In this case, I chose a lesser-known novella to compliment Boccaccio's more famous narratives. The reasons for my selection are intrinsically tied to the reasons why some tales are, in fact, less widely known. Today, there is great enthusiasm by a diverse body of scholars for exploring questions of gender, and of how canonical literature reflects the misogynist or feminist attitudes of a given time, with a secondary goal being to underscore and/or seek to remedy the inequities of the present day. Similarly, the study of animals, which were viewed in the past as either literary symbols or practical tools, is gaining ground. There is material for both of these pursuits in novella IX.7. As readers and scholars, we also gain a larger understanding of how these themes were represented in a work or by an author when we approach them from multiple angles, which also provides students, who may not be able to read the entire text, with a better understanding of the work as a whole. Finally, such a varied selection of texts can encourage students to more confidently explore their own research interests, and, perhaps, serve as visual inspiration for upcoming artists. The selection process, itself, could be part of a class discussion.

In this particular lesser-known tale, the wolf is described as immediately latching onto the wife's throat in both the dream version and in the real attack that follows when she refuses to heed her husband's warnings. The narrator, Pampinea, emphasizes the woman's total inability to scream under the grip of the wolf's jaws in the actual attack. This is a point at which the bestiary can be recalled in class, with projections of early bestiary images accompanied by medieval expositions of their characteristics. Margherita's incapacity to speak is consistent with a mysterious power wolves were said to possess-one that is a frequent subject of visual representation in the bestiaries and is referred to in literature dating back to the first century: if a wolf sees a person before it itself is seen, the person temporarily loses the ability to speak, whereas if the person sees the wolf first, the wolf loses its ferocity. ${ }^{5}$ It is clear that, despite her husband's premonition, Margherita is wholly surprised by the wolf that had been stalking her. In this sense, the attack is the "realistic" outcome of the wolf's reputed power. However, the properties of the creatures populating the bestiaries were also used as allegories for human behavior. Therefore, Margherita's silencing might also seem a contrapasso-like punishment for her refusal to quietly yield to her husband's authority. Similarly, the wolf serves as a means of controlling what wolves themselves represented through their connotations not only with prostitutes, but with women in general: insatiable sexual desire, viewed in medieval Italy as a widespread and dangerous female propensity. Margherita, now maimed, has lost the ability to entice through her beauty.

In my experience, most students view the medieval bestiaries with great interest, and they embrace learning about properties once attributed to animals that seem so counter-intuitive today. In class, the bestiary illustrations can be used to further underscore how the perception of animals has changed since the Middle Ages. When students examine the images of wolves, it is made clear to them that these depictions are not intended to be accurate representations of wolves in nature. Most of them are quite dog-like, which is one way of portraying this close relative of the domestic dog, but others look more like bears or foxes, or have coats that are spotted or tiger-striped, and some sport manes like lions. Many are shown creeping up on sheep, or savagely biting their own paws (to punish them for making a sound) (see [11]). Actual wolves had become scarce in Italy by this time, so an extra level of ingenuity was required to depict them on the part of the artist. However, more importantly, these illustrations make it clear that the artist does not intend to create a realistic portrait; rather, these

5 See David Badke [11] for more details, including excerpts from Pliny the Elder (first century) and Bartholomaeus Anglicus (thirteenth century) on this characteristic of the wolf. It is also mentioned by Albertus Magnus ([12], p. 1518). 
are images representing creatures whose significance lay in the spiritual or moral lessons they were used to impart.

Illustrated manuscripts, as with the Commedia, can be another tool used to reinforce the Decameron. While representations of this particular novella are not numerous, students can also benefit from seeing illustrations of other tales. The style and composition of the images in these manuscripts remind students that, despite dramatic differences in literary style and content, Boccaccio's masterpiece came not long after that of Dante. The illustrations help to bring the two works closer together.

In the Middle Ages, wolves were shadowy, mysterious creatures, and the idea of roaming wolves preying on humans embodied the threatening chaos of the wilderness ([9], p. 4). The episode of Margherita recalls the Inferno through this terrifying imagery of the stalking wolf as well as its wooded setting, although Margherita's beautiful woods-“bosco assai bello" ([13], IX.7.5), is quite different from the dark wood of the Inferno. This is not the only beautiful wood in the Decameron that is the venue of a horrifying canine attack - there is another in one of the most well-known novelle of the text: the 8th tale of Day V, featuring Nastagio degli Onesti. However, in Nastagio's tale, dogs are the aggressors rather than wolves.

\section{Wolves to Dogs}

At this point, our exploration shifts from wolves to dogs. Students are asked to express their own thoughts on the two, including whether they feel differently about them, and why. Wolves remain controversial today and can elicit a wide range of responses, from fear to admiration. Their domestic counterparts, predictably, elicit more affectionate associations. These differences can be introduced through the use of ambiguous bestiary images themselves. Do depictions of wolves that resemble dogs make some viewers feel more favorably towards the animal? Or are a viewer's reactions based more strongly on the animals' behavior in these portrayals? Students are also asked to express whether they would feel differently if a dog were represented in place of a wolf in the literary selections we have read, and why. The goal of such discussions is to make students aware of how their emotional reactions may color their interpretations of works in which these animals appear. As a class, we then examine how dogs were viewed in the Middle Ages and early Renaissance, which allows students to consider the texts in a more contemporary context. This topic can be introduced through class discussion, but the instructor may prefer to provide excerpts from representative texts in order to fully study the aspects described here.

Although dogs and wolves are closely related, the domesticity of the one and the wildness of the other would seem to be reason enough for literature to treat them as highly distinct. Indeed, the great majority of the animals in the Decameron are domestic beasts, so the appearance of dogs is more consistent with the rest of the text. In the Middle Ages, dogs were companions and status symbols, with the wealthier classes boasting of skilled hunting dogs for men and companion lapdogs for women ([9], p. 5). ${ }^{6}$ Dante uses the metaphor of a veltro, a noble greyhound, as the savior who will eventually rout the evil lupa ([3], Inf. I v. 103)—one of three types of dogs valued for hunting and described by Albertus Magnus in the De animalibus in the thirteenth century ([12], pp. 1457-59). Dogs were lauded for their wisdom and reputed to be capable of recognizing angels, and even Brunetto Latini remarked on their adoration for humans. ${ }^{7}$

Despite these warm praises, references tying dogs to sin, the devil, and sexual perversion abound in medieval and Renaissance writings ([2], pp. 60-61), and their consistently negative portrayals in

6 Hunting with falcons and packs of hounds were pursuits linked with wealth and nobility; archery, hunting with one or two dogs, trapping, and other less prestigious methods were used by those hunting for food, as described in ([14], pp. 61-63).

7 Cassell and Kirkham note this trait of wisdom, as well as the dog's reputation for moderation, in their explanation of the influence of the bestiary tradition on Boccaccio's Caccia di Diana ([15], p. 186). For the reference to Latini, see ([16], p. 16). 
Christian doctrine are represented alongside their positive characteristics in the bestiaries ([9], p. 25). ${ }^{8}$ These attributes are quite similar to those of their relatives, the wolves. Dante's text seems to associate dogs with their wild relations as well, not only through the environments in which they lurk, but also in the words that describe them. In the Inferno, dogs, like wolves, are described as voracious brutes. Cerberus, the barking three-headed dog that both guards and torments the gluttons, has gullets described as "bramose" (ravenous) ([3], Inf. VI v. 27); the same adjective used earlier for the she-wolf. Boccaccio reiterates this in the Esposizioni, where he commends the choice of Cerberus for this particular canto since "ogni cane naturalmente è guloso" (all dogs are naturally gluttonous) ([7], VI.II.51, 54; [8], p. 328). However, does Boccaccio extend this association into his own, original writing?

Given the fact that the Commedia's beasts are generally fantastic or allegorical, and the Decameron's are typically commonplace, living creatures, one might expect marked differences in their portrayals. Yet both texts reveal a common outlook on the canine family, and the Decameron echoes the Commedia's blurring of the distinctions between dogs and wolves. In fact, the wolf in Margherita's tale was described with the adjectives, "grande" (large) and "fiero" (fierce), and these are the very same adjectives used to describe the dogs in the tale of Nastagio degli Onesti, which is assigned in class for reading before the next lesson.

\section{The Tale of Nastagio degli Onesti}

In novella V.8, Nastagio, lost in thought over his hopeless love, wanders into a pine forest where he witnesses a savage, otherworldly scene. In the woods, he is startled by the sight of a beautiful girl, "ignuda" (naked) and "graffiata" (torn), crying for mercy, and at her flanks, "due grandi e fieri mastini, li quale duramente appresso correndole spesse volte crudelmente dove la giugnevano la mordevano" (two huge and ferocious mastiffs that every so often would catch up with her and bite her savagely) ([13], V.8.15-16; [17], p. 360). This scene recalls the myth of Actaeon, ripped apart by his own hunting dogs after seeing Diana nude-but Diana had first transformed Actaeon into a stag, making him prey, whereas this victim is still human.

Critics have noted that Boccaccio's tale shows the influence of the religious exempla; short narratives intended to illustrate the perils of sin and the rewards of salvation. Its infernal hunt closely resembles one in the Specchio della vera penitenza ([18], pp. 46-48), a collection of sermons delivered by the Dominican friar Iacopo Passavanti in 1345. This particular exemplum features the vision of a fire-breathing knight on horseback pursuing a terrified naked woman, whom he then stabs and throws into a fire; an otherworldly scene that must play out repeatedly until both souls have served their penance for an adulterous affair and murder committed while they lived. The tale has many key similarities to Boccaccio's tale; but one major difference is that no dogs appear in Passavanti's version. The source that may have played a larger role for this aspect of Boccaccio's tale is that of Dante's spendthrifts in Inferno XIII. These poor souls, recklessly and self-destructively wasteful of their possessions in life, are forever fleeing through the Wood of the Suicides, and they, too, are described as "nudi e graffiati" (naked and torn) ([3], v. 116). They are pursued and mauled by "nere cagne, bramose e correnti" (black bitches, eager and fleet) ([3], v. 125). The sounds that precede the emergence of the spendthrifts are compared to those of a wild boar hunt, and the dogs are eager, "come veltri ch'uscisser di catena" (like greyhounds loosed from the leash) ([3], v. 126), although no human hunter is present. The souls condemned to eternal canine dismemberment are destructive squanderers of wealth. Nastagio, likewise, is introduced as one who, in his fruitless pursuit of love, had both

8 In the Bestiario toscano, for example, the dog is said to be faithful to its benefactors, but the true focus of the discussion is what is described as its repulsive habit of reingesting its own vomit. The vast majority of the entry on dogs is dedicated to explaining how repeated sinning by humans is analogous to the dog's loathsome behavior ([10], pp. 28-30). 
considered suicide and, due to his continued lavish spending, "sé e ' 1 suo avere parimente fosse per consumare" (was on the brink of wasting away both himself and his fortune) ([13], V.8.9; [17], p. 359).

Visual images can be used to reinforce this connection after the class is asked to recollect (or read) Inferno XIII, and to produce their own classroom sketches of both Boccaccio's and Dante's wooded scenes. The Renaissance artist Sandro Botticelli is an ideal choice to follow this drawing activity not only because he produced illustrations for the Commedia, but also because he created the most well-known depictions of Boccaccio's novella V.8.

Botticelli's rendering of Inferno XIII (c. 1480-95) is an outline drawing on parchment. While it was intended to accompany the text, it is different from earlier illustrated versions of the manuscript due to the size of the drawing and the fact that it is separate from the text. Botticelli had a strong interest in Dante, and the illustration reflects this, with all of the action from the canto compressed into one scene. It is a delicate and yet very elaborate drawing, with beasts, humans, and trees merging almost indistinguishably into one another-as is appropriate given the content of a canto in which condemned souls are transformed into a dense, gnarled forest. The drawing takes some attention to decipher, especially given its faded condition, and therefore a grasp of the canto's content is essential before viewing it in class in order to avoid imbuing the scene with additional confusion. A close look reveals the squanderers with dogs in pursuit scattered throughout the infernal wood. We can also discern the pilgrim and his guide in both the upper right corner and lower left. The repetition of figures within one frame, as well as the flat plane they populate, are reminiscent of earlier illustrated versions, and allow students to see the thread connecting past traditions with newer artistic innovations.

Drawing the connection between Boccaccio's tale and the episode in Dante is notable because, despite Boccaccio's obvious familiarity with Dante's scene, the novella involving his own spendthrift-protagonist has a very different outcome. Unlike Dante, Boccaccio does include a huntsman in his episode-a knight who arrives on a black horse, "forte nel viso crucciato" (his face flushed with anger), yelling for Nastagio to allow him and the dogs to punish "questa malvagia femina" (this wicked woman) as she deserves ([13], V.8.16, 19; [17], p. 360). His "lascia fare a' cani e a me" (leave it to me and these dogs) is an apt choice of words, for here human and beast are joined not only semantically, but also through the traditional associations of dogs with wrath. The knight stops speaking, and "a guisa d'un cane rabbioso" (like a mad dog) he cuts his victim open with his sword and feeds her entrails to his dogs, who immediately devour them with ravenous hunger ([13], V.8.29; [17], p. 361). In the Inferno, the dogs themselves dismembered their victims; here, the dogs require the intermediary of their doggish master before they can feast. This, Nastagio learns, is an infernal scene that repeats itself over and over. The knight is a soul lost to suicide—another link to Dante's Inferno XIII—due to the unrequited love of the woman he and his dogs continually hunt and dismember.

It is worth pointing out to students that, in his expositions on the Inferno, Boccaccio claimed that the spendthrifts were torn apart by dogs in proportion to the number of afflictions they endured in poverty, and that their consciences were torn "da amarissime rimorsioni" (by exceedingly bitter remorse) ([7], XIII.II.16; [8], p. 350). But Nastagio, the spendthrift and potential suicide, does not interpret this violent, infernal vision as a message for him, nor does he undergo a crisis of conscience. Instead, he decides that what he saw "dovergli molto poter valere" ([might be very] useful to him) ([13], V.8.32; [17], p. 361). By orchestrating a feast where his love object witnesses the scene and then, from terror, agrees to marry him, he teaches a lesson not only to her, but also to all the women of Ravenna who, from then on, are said to be much more amenable to their men's desires. Once again, as with Margherita, we see female characters who are unable to speak fully in this tale. One is the mute victim of an endless infernal attack, and the other a living woman who only speaks, indirectly, to offer herself to Nastagio after coercion through fear, and both are brought to heel by animals associated with unbridled desires.

Sandro Botticelli also depicted scenes from this particular tale, and though he undertook this more than a century after the novella's creation, the artwork makes such an impact that author and artist might now seem inextricably linked. Botticelli painted four panels with tempera, c. 1483, at the request of his patron for his son's wedding (see [19]). The first panel, on which we spend the most time 
in class, shows the scene as Nastagio sees it first in the wood. Nastagio appears twice in this panel; first, lost in thought, and then, at the defense of the girl being pursued. The painting, unlike the Inferno illustrations, is fully executed, with rich color, delicate lines, and depth. The wood is peaceful and luxurious, with lush greenery, grazing animals, and quiet waters-an unlikely locus amoenus for such a gruesome scene. However, the flashes of red in the attire of the knight and of Nastagio highlight the violence of the scene and herald what will happen next. The visual power of the artwork heightens the students' awareness of this clash between the pastoral setting and the savage pursuit.

A setting for love is not completely at odds with a bloody hunt, however. Earlier fictions, including Boccaccio's own, used hunting as a metaphor for amorous pursuits, as the hunting term "venery" itself implies. Boccaccio's Caccia di Diana, for example, featured an elaborate hunt in which the animals served a function similar to the one they served in the Commedia: they are strictly symbolic, each beast representative of an evil or sin that the ladies of the hunt conquer and then transform through their virtues. ${ }^{9}$ There, the hunted beasts served as a means for Boccaccio to exalt the women who were able to, metaphorically, conquer vice through the ennobling power of their beauty and love. The text is an allegory rich with bestiary symbolism, and it demonstrates the breadth of Boccaccio's knowledge in this area. But in V.8, the hunt is not used to exalt women-instead, its purpose here is inverted; it used for another type of amorous pursuit, based on violence and coercion.

The hunting dogs in the novella of Nastagio, like the wolf that attacked Margherita, highlight sexual difference and the forced resolution of sexual conflicts-a conflict also apparent in the hunt's terminology of gender. Dante's hunting dogs in pursuit of the spendthrifts are female, but in Boccaccio's text, Margherita's wolf is a masculine lupo, and the dogs in the novella of Nastagio are also referred to in the masculine form, sometimes as "mastini" (mastiffs) and at other times as "cani" (dogs). Despite the influence of his source, Boccaccio has chosen to have his female victim hunted by male dogs.

Other aspects of the tale also emphasize an imbalance of power. The contrast between the otherworldly victim and her hunter is stark in Boccaccio's tale. She is young, naked, and on foot; he is a knight armored and astride a charger (another symbol of high status), and aided by savage dogs. His appearance and his possessions denote nobility and also, due to the sport in which he is engaging, masculinity; whereas the nudity of the fleeing victim displays her vulnerability and eradicates any markers of status whatsoever. Even the knight's act of feeding his victim's heart and organs to the dogs underscores her lowly status. In the Middle Ages and Renaissance, it was common for hunters to reward their dogs by feeding them the entrails of their catch as part of the ceremonial rituals of the hunt ([14], p. 61). With this gesture, Boccaccio's knight is demonstrating the worth of his dogs in reverse proportion to the worth of his human victim. This dichotomy is further reinforced by the dogs, notably called "mastini" (mastiffs) in this section of the tale ([13], V.8.16; [17], p. 360). Although mastiffs were sometimes used in the hunt, they were not as valued as other types of dogs in the sport ([14], p. 61). This lowly quarry apparently does not merit the use of the best weapons in the wealthy hunter's arsenal.

Such close explorations of the dogs in novella V.8 can be carried into an examination of the Botticelli paintings, as well. In the first tempera panel, there are a number of adaptations to the original tale. Boccaccio's victim is naked, whereas Botticelli's girl is adorned with a wisp of fabric strategically draped to conceal her sexual attributes. While this is a concession to contemporary ideas of modesty, the contrast between fabric and flesh also, ironically, underscores her nudity. The knight has been changed from dark to colorful and bright, with glittering gold in his armor and a bold red cape; and his horse is now white instead of black, which was its original color in both Boccaccio's and Passavanti's versions. It seems unlikely that these changes were due to a lack of familiarity with the tale, especially

9 Victoria Kirkham reads the allegory as not only the defeat of vice by virtue, but also one "of conversion from bestial lust to Christian love" ([20], p. 304). 
when other details, such as the stick Nastagio seizes to defend the fleeing girl, is featured in the painting. It may be that the colors were chosen to enhance the composition of the painting since white and other light colors stand out against the dark shades of the wood, bringing these figures to the forefront. However, white is a color often featured on the chargers of victorious or heroic knights in artwork, as well as being a color long associated with goodness, purity, and innocence. Even today, viewers are likely to associate a dark horse and rider with a sinister threat. A shift away from the original colors downplays the infernal nature of the scene, underscoring instead its tragic element and the realization that both the knight and the girl are victims to fate.

The dogs, too, have undergone a change. Rather than two savage mastiffs-dogs of enormous size and bone with massive jaws and heads-we are presented with one lightly-boned white dog that much more closely resembles a greyhound or other fleet-footed sight hound, and a barely-visible black dog mostly obscured by the victim's body. The dog in the foreground seems to represent the top of Albertus Magnus' ranking of hunting dogs, where greyhounds, like Dante's veltro, are the most highly valued ([12], pp. 1457-59). This further accentuates the scene's tragic nature and downplays the sinister imbalance between the genders represented by the two condemned souls.

The second episode depicted by Botticelli is more gruesome. The knight is atop the girl, ripping her back open as Nastagio recoils in horror and the dogs devour her entrails in the corner. The body of the white dog is foreshortened, while the black dog is now fully visible. In the distance, we see the scene repeating itself with the mounted knight and white greyhound pursuing the girl once more. This episode is jarring, and the small changes add to its disturbing content; evisceration, after all, is an important part of the tale and is not an act that can be easily minimized. Nonetheless, the beasts in the peaceful wood continue to calmly graze and drink, with only a casual glance back towards the action. The third and fourth episodes of the tale display not only the realism of their subjects, but also Botticelli's mastery of the highly valued rules of perspective, particularly striking in the architectural structure featured in the final wedding feast scene.

Botticelli's paintings of V.8 can be used in the literature classroom to inspire debate about what Boccaccio intended in the original tale, and about how later generations chose and choose to interpret his message. It also demonstrates the increased value of realism in the visual arts during the Renaissance period, even as these paintings continue to show traces of the symbolism animals traditionally represented. These visual works also illustrate the inability to separate art from its context. The last two episodes reflect Botticelli's reality more than Boccaccio's, for they move away from the city of Ravenna and on to Florence, to Botticelli's patron, and to the wedding for which the series was commissioned.

Gender imbalances, along with conflicting attitudes about the legitimacy of desire in the sexes, are a central and recurring feature of this novella, and of each selection discussed in relation to our canine theme. Students should be encouraged to share their reactions with their classmates, and to examine how their own experiences or attitudes may shape those reactions. Nonetheless, not all students are comfortable sharing thoughts or experiences about issues that may have impacted them personally, and some are more comfortable expressing their feelings in assignments submitted to the instructor alone. Reflection journals and final papers encouraging students to provide their own interpretations provide a means for these thoughts to be expressed. In class, however, it has been my experience that students openly express surprise and discomfort at the idea that this novella was selected as the subject to commemorate a wedding, considering the violence of the tale, the objectives of that violence, and the way in which its own "happy" wedding comes about. If Nastagio (and the author himself) used the infernal scene as a message to an unwilling love-object, what sort of messages were the paintings supposed to convey, and to whom? Does the softening of the hunter's image in the Botticelli paintings change that message in any way? Each student must determine his or her own answer to these questions.

In conclusion, what is learned by exploring artwork inspired by the literature we are studying is significantly more enriching than a focus on the literature alone. The Decameron presented a new way of 
interpreting the human experience to the world, and this is reflected in the portrayal of its canids, even as they continue to share many qualities with their medieval antecedents. The beasts of the Decameron are more lifelike than their predecessors, and though they retain some of their traditional symbolism, they are multifaceted. Its wolves and dogs move away from a purely symbolic role to a more active one, functioning as agents of change within the stories themselves. They now serve as "exemplars" of a morality based on an ironic examination of human nature, heralding the Renaissance's shift away from the intense medieval focus on spiritual guidance. Similar shifts can be seen in the artwork that represents these tales, and its presentation brings this to vivid life in the classroom.

The discussions that artwork can inspire, as well as the artwork the students themselves seek to create in class, enhance the learning process and deepen the classroom experience. A culminating activity for the class is a visit to the nearby rare library, where students are able to see, read, and touch ancient editions of these literary and illustrated texts. In an era of digital sources, this small fieldtrip can bring these works fully to life. Underlying all of these activities is the conviction that a multifaceted approach to literature teaches our students to explore both word and image with a critical eye, and to formulate and express their own views. The interpretation of the works of Dante and Boccaccio, through their canine representations, demonstrates that literature and the visual arts support one another in class. Each enhances the enjoyment and understanding of the other, while facilitating students' ability to look deeper into these works and to make their own critical judgments. Reinforcing these lasting and invaluable skills in our students is worth any extra effort required.

Conflicts of Interest: The author declares no conflict of interest.

\section{References}

1. Cristina Mazzoni. She-Wolf: The Story of a Roman Icon. New York: Cambridge University Press, 2010.

2. Beryl Rowland. Animals with Human Faces: A Guide to Animal Symbolism. Knoxville: University of Tennessee Press, 1973.

3. Dante Alighieri. The Divine Comedy: Inferno. Edited and translated by Charles S. Singleton. Princeton: Princeton University Press, 1989.

4. Jackie Andrade. “What does Doodling do?" Applied Cognitive Psychology 24 (2010): 100-6. Available online: http://onlinelibrary.wiley.com/doi/10.1002/acp.1561/abstract (accessed on 15 January 2016). [CrossRef]

5. Bodleian Library. "Bodleian Library: Western Manuscripts to c. 1500: Ms. Holkham misc. 48: Inferno." Available online: http://www.bodley.ox.ac.uk/dept/scwmss/wmss/medieval/mss/olkham/misc/048.a. htm (accessed on 14 January 2016).

6. "Details of an Item from the British Library Catalogue of Illuminated Manuscripts: Yates Thompson 36." Available online: http://www.bl.uk/catalogues/illuminatedmanuscripts/record.asp?MSID=6468 (accessed on 12 January 2016).

7. Giovanni Boccaccio. Esposizioni Sopra la Comedia di Dante. Edited by Giorgio Padoan. Verona: Mondadori, 1965.

8. Giovanni Boccaccio. Boccaccio's Expositions on Dante's "Comedy". Edited and translated by Michael Papio. Toronto: Toronto University Press, 2009.

9. Brigitte Resl. "Animals in Culture, ca. 1000-ca. 1400." In A Cultural History of Animals in the Medieval Age. Edited by Brigitte Resl. Oxford: Berg, 2011, pp. 1-26.

10. Milton Stahl Garver, and Kenneth McKenzie, eds. Il Bestiario Toscano Secondo la Lezione dei Codici di Parigi e di Roma. Rome: Società Filologica Romana, 1912.

11. David Badke. "The Medieval Bestiary." Available online: http:/ /bestiary.ca (accessed on 14 January 2016).

12. Albertus Magnus. On Animals: A Medieval "Summa Zoologica". Translated by Kenneth F. Kitchell, Jr. and Irene Michael Resnick. Baltimore: Johns Hopkins University Press, 1999, vol. 2.

13. Giovanni Boccaccio. Decameron. Edited by Vittore Branca. Turin: Einaudi, 1992, vol. 2.

14. An Smets, and Baudouin van den Abeele. "Medieval Hunting." In A Cultural History of Animals in the Medieval Age. Edited by Brigitte Resl. Oxford: Berg, 2011, pp. 59-80.

15. Giovanni Boccaccio. Diana's Hunt-Caccia di Diana: Boccaccio's First Fiction. Edited and translated by Antony K. Cassell and Victoria Kirkham. Philadelphia: University of Pennsylvania Press, 1991. 
16. Alberto Manguel. “Dante's Dog.” PN Review 192 (2010): 14-18.

17. Giovanni Boccaccio. The Decameron. Translated by Mark Musa and Peter Bondanella. New York: Mentor, 1982.

18. Iacopo Passavanti. Lo Specchio Della Vera Penitenza, 2nd ed. Edited by Filippo Luigi Polidori. Florence: Felice le Monnier, 1863. Available online: https://archive.org/details/lospecchiodellav00passuoft (accessed on 29 May 2016) (Internet Archive).

19. Emil Krén, and Daniel Marx. "Web Gallery of Art: The Story of Nastagio degli Onesti." Available online: http://www.wga.hu/frames-e.html?/html/b/botticel/6nastagi/index.html (accessed on 12 January 2016).

20. Victoria Kirkham. “Numerology and Allegory in Boccaccio's Caccia di Diana." Traditio 34 (1978): 303-29.

(C) 2016 by the author; licensee MDPI, Basel, Switzerland. This article is an open access article distributed under the terms and conditions of the Creative Commons Attribution (CC-BY) license (http://creativecommons.org/licenses/by/4.0/). 